(2) The Paniselian is sometimes regarded as having been formed in deeper water than the Bruxellian.

(3) Recent study of the fauna seems to show that the fossiliferous horizon in the Flanders Clay at Bailleu, Ploegsteert (near Messines), etc., marks the base of the Lutetianl (Paniselian facies), and that the Belgian geologists have been correct in regarding the series of sandy clays in the higher part of the "Argile des Flandres" as Paniselian.

\title{
The Boulders of the Travellers' Rest Gravel Pit, Cambridge.
}

\author{
By J. E. A. Whealler, Christ's College, Cambridge.
}

A BOUT twelve years ago Dr. R. H. Rastall and Mr. J. Romanes A published an account of the Boulders of the Cambridge Drift. ${ }^{1}$ In this paper a list was given of the rock-types recognized at that time in the gravels of the Travellers' Rest Pit, situated about a mile north-west of the town of Cambridge on the Huntingdon Road. Since that time Professor Marr has paid much attention to this pit, among others, with special reference to the Palæolithic implements there found. He has embodied his results in two important papers. ${ }^{2}$ In the course of this work Professor Marr collected a number of interesting erratics, and the same pit has also been investigated by many geologists connected with the University, both members of the Sedgwick Club and others. During the last ten years, though the North Pit has been abandoned, the South Pit has been very actively worked for gravel, and has been greatly increased in size. In consequence of this a large amount of additional material has been collected, including many new types, while some of the older specimens, whose origin had been left indeterminate by Rastall and Romanes, have been now identified. Hence it is felt. that the time has now arrived when these more recent results should be put on record.

The Travellers' Rest Pit is excavated in the "Gravels of the Ancient River System " of the earlier literature. It is not proposed here to discuss its stratigraphical relations. On this point reference may be made to Professor Marr's recent publications, especially to the Q.J.G.S. paper, in which a sketch is given of the "face" of the pit. It is intended in this paper only to deal with the erratics found in the gravels.

The list given by Rastall and Romanes in their paper is as follows :-

Carboniferous Limestone, several, some striated.

Millstone Grit, several.

$\left.\begin{array}{l}\text { Basalts } \\ \text { Dolerites }\end{array}\right\}$ large and unusually well rounded.

1 Quart. Journ. Geol. Soc., rol. Ixv, 1909, p. 246, et seq.

2 Quart. Journ. Geol. Soc., vol. lxxv, 1919, p. 204, et seq. ; and Proc. Camb. Phil. Soc., rol. xix, 1917, p. 64. 
Rhomb-porphyry (ㄹ) .

(?)Nordmarkite.

Pink granulitic granite, two large specimens.

Orthophyre of North Berwick type.

(?) Analeime-dolerite (Teschenite) of Forth Valley type.

Cheviot porphyrite and lava.

Coarse white granite.

Large concretion with Serpula tetragona.

A species of Gryphaca, intermediate between arcuata and dilatata.

To proceed to a detailed description of the new types recorded. The specimens may be classified according to their reputed source of origin, which sources may be conveniently divided as follows :-

1. Scandinavia.

2. Scotland and Scottish borders.

3. Lake District.

4. North-Eastern and Eastern England.

5. Source unknown.

Of necessity the majority of specimens are allocated to the last class.

To deal with the divisions severally, commencing with the Scandinavian types. The only specimens which had been recorded at the time of publication of Rastall and Romanes' paper, were rhomb porphyry and a doubtful nordmarkite, or, rather, I should say, these were the only certain types. Since that time several more specimens of rhomb porphyry have been collected, notably by Professor Marr, one of which is remarkably large, measuring 12 by 11 by 7 inches. This rock, however, is far from common at the Travellers' Rest Pit, though it is found in greater abundance elsewhere in the Cambridge district. Laurvikite, which has been recorded from the district before, has been collected at the pit, once only I believe, and that specimen a small and badly weathered one. One small specimen of the pink soda granite of Christiania has been collected.

Perhaps the most important discovery from the pit, however, is a small boulder with a violet-brown groundmass, in which are scattered grains of quartz, small orthoclase felspars, and greenish plagioclase. This corresponds therefore very closely with the Särna porphyry, according to Milthers'1 description of that rock. A second specimen has recently been collected bearing a strong resemblance to the last, but with a smaller amount of quartz and without plagioclase, so far as can be seen by the naked eye. The groundmass also is dark grey, rather than violet-brown. This strongly resembles the specimens of the Elfdal porphyry in the Natural History Museum. These rocks therefore belong to the Dala group of porphyries, as described by Milthers, a type not hitherto recognized in this neighbourhood. On looking through the collection

1 Milthers, Indicator Boulders, D.G.U. II, R. Nr. 23, Copenhagen, 1909 ; and Geschiebe aus der Umyegend von Königsberg in Ostpreussen, Phys.ök. Gesell. zu Königsberg, 1888. 
made by Rastall and Romanes, no less than six boulders tere found bearing a strong resemblance to them. They were collected from the following localities :-

(a) Two from fields north of the Madingley Road, 5 miles from Cambridge.

(b) Gravel pit, Milton Road.

(c) Deep Spring, Biddenham, Bedfordshire.

(d) Two found east of the "Golden Lion", Kingston.

Särna is in the Dala district a few miles from Elfdal itself, and about 200 miles north-west of Stockholm. The presence of Dala boulders in England has (according to Milthers) been reported rather indefinitely before. ${ }^{1}$

The important Swedish indicator boulder-the Scanian basalthas not been definitely found at the pit, but basalts are extremely common, and, owing to the multiplicity of Scottish types and the similarity of basalts generally, no definite results have been obtained.

Three interesting nordmarkites were collected last year. One on a heavy mineral separation yielded a quantity of copper; the other two were sliced, one having a special peculiarity in that riebeckite is developed instead of arfvedsonite, and the other shows strong affinities to this rock.

Three extremely interesting boulders were collected last year, all probably Scandinavian, but their exact locality is uncertain. The first type has been found twice and is a porphyry with extremely fine felspar phenocrysts up to $10 \mathrm{~mm}$. in length, and showing intact crystal faces; the greyish-white groundmass contains abundant green specks which on microscopic examination proved to be agirine. The second specimen is a gabbro with some affinity to the essexites: it contains some orthoclase, and the uralitic hornblende is blue in places, showing derivation from a soda-bearing augite. The other rock was collected as a largish boulder, and is a syenite with lepidomelane, and was found, when a slice was examined, to contain barkevikite. Neither this rock or the ægirineporphyry could be matched in the collection of Scandinavian rocktypes at South Kensington Museum.

The complete list of Scandinavian types which have been recognized at the pit may be summarized thus :-

Swedish.-Särna porphyry and related types.

Norway: 1. Rhomb-porphyry.

2. Laurvikite.

3. Christiania soda granite.

4. "Copper-bearing" nordmarkite.

5. Riebeckite-nordmarkite.

6. Nordmarkite showing affinities to No. 5 .

Doubtful : Barkevikite-syenite.

Agirine-porphyry.

1 Indicator Boulders and V. Madsen, Quart. Journ. Geol. Soc., rol. xlix, 1893 , p. 114 . 


\section{J. E. A. Whealler-Boulders of Cambridge Gravels. 203}

It is of interest to note that a boulder collected some time ago at Whitby by Dr. Rastall bears a marked resemblance to the Bredvad (Dala) porphyry, described by Milthers.

Turning now to the Scottish types many interesting specimens have been collected.

Firstly, we have the quartz-porphyry from Buchan Ness. This rock has fine phenocrysts of orthoclase, and plentiful quartz grains embedded in a dark, fine-textured groundmass. It is recorded by Rastall and Romanes as being found at Barrington, an exposure now unfortunately largely overgrown. The Barrington specimen was identified as the Buchan Ness rock by Dr. Bonney and Dr. R. Campbell. This year three specimens have been recorded from the Travellers' Rest Pit, but I am not aware of any having been found here previously. Two of the specimens were moderately large and in good preservation.

The next rock of interest is a beautiful alkali-granite with fine crystals of pink felspar and occasional patches of dark ferromagnesian mineral. I submitted this specimen to Dr. Bonney, who remarked on its strong affinities to both the Ross of Mull and Peterhead granites, the resemblance to the latter being more pronounced; the possibility of its being a specimen of the former being out of the question, and the finding of the Buchan Ness rock just referred to, seem to indicate its being of Peterhead origin. One specimen only has been recorded.

The finding of the Buchan Ness and Peterhead rocks here gives excellent proof of the presence of North Aberdeenshire erratics in the Cambridge drift, and touching on the interesting question as to how they reached this district, new facts have lately come to light. On the map on p. 49 of Mr. W. B. Wright's Quaternary Ice Age, the ice flow on the North Aberdeenshire coast is shown as roughly northerly. From this the inference might be that these types were transported indirectly, had it not been for a recent important discovery. In the report of a recent meeting of the Edinburgh Geological Society ${ }^{1}$ there is an account by Dr. Bremner of the finding of a boulder of rhomb-porphyry at the Bay of Nigg, just south of the town of Aberdeen, and about 30 miles south of Buchan Ness. This discovery is of the utmost importance, showing as it does that the Scandinavian iee did reach the mainland of Scotland, and would therefore be sufficiently strong to deflect the easterly flows of the Highland ice in this district, in part at any rate, in a southerly direction, and thus probably accounted for the transport of the Buchan Ness and Peterhead rocks to Cambridgeshire.

The quartz-porphyry recorded from so many localities, not, however, including the Travellers' Rest, by Rastall and Romanes, and referred to by them as porphyry " $x$ ", has now been identified as being a Scottish type, where it is of fairly wide distribution, being

1 Grol. MaG., vol. lvii, 1920, p. 522. 
a dyke rock of Old Red Sandstone age. It has lately been collected several times at the Travellers' Rest Pit, and can be easily recognized by the weathering out of the quartz grains on the "boulder surface" as black specks.

Cheviot rocks are common and call for no further notice, except that many types are found, including andesites, porphyrites, and porphyries.

Several boulders have been collected of the Old Red Sandstone, which must be erratics from either the outcrop at the Border or from that north of the Firth of Forth.

One of the basalts collected at the pit was sliced, and both the boulder and the slice were submitted to Mr. E. B. Bailey, of the Geological Survey of Scotland. He stated that this specimen was a basalt of the Dalmeny type, approaching in its richness in augite phenocrysts and poorness in felspar in the groundmass to the Hillhouse type, and would be matched exactly under par. $b$, p. 106 , E. Lothian Memoir (1910).

With regard to the presence of Lake District rocks in this district, more and more evidence is being collected in favour. At the time of publication of Rastall and Romanes' paper the finds were as follows :--

$\left.\begin{array}{l}\text { Muscovite granite porphyry } \\ \text { Andesite }\end{array}\right\}$ Kingston Lodge.

Andesite with old label: "Drift, Cambridge".

Andesite with old label: "Observatory, Cambridge".

All these andesites are remarkably similar to the andesites of the Borrowdale series. They are well-preserved, compact, darkgreen rocks, in which are embedded small laths of felspar. Since then two more specimens have been collected, one in 1909 , after the publication of the paper by Rastall and Romanes, at the Milton Road Pit, and one last year at the Travellers' Rest. Thus five similar specimens have been found, all bearing very strong resemblance to the Borrowdale lavas.

The muscovite granite porphyry confirms the other specimens, as it is identical with the Dufton Pike rock.

The cumulative evidence of these types really forces one to the conclusion that Lake District rocks have been transported to the Cambridge area.

With regard to class 4 , the north-eastern and eastern English rocks, the following have been found :-

Millstone Grit.

Coal-measure sandstone.

Carboniferous limestone.

Jurassic " oyster bed".

- Several other sandstones (common).

Porospheræ.

? Red Chalk. 
The latter calls for special caution owing to its great similarity to the Silurian Orthoceras Limestone from South Sweden. Unless a specimen contains a fossil it is impossible to state definitely which rock it is.

Noticeable under this heading is the Palæolithic implement found by Professor Marr, which is made from a silicified oolite which Dr. Rastall has identified as being of Yorkshire origin. The rocks from unknown localities are as follows :-

(a) Metamorphic:

1. Garnet-mica-schist.

2. Hornblende-schist, with quartz veins.

3. Green mica-schist, turning brown in places.

4. Micaceous schistose conglomerate (quartz pebbles).

5. Gneissose granites (comparatively common).

6. Foliated granite with porphyritic microcline.

7. Very much altered gabbro.

8. Gneissose muscovite-biotite-granite.

9. Many quartzites of varying composition.

(b) Igneous.

1. Muscovite-granite-porphyry.

2. Microgranites, chiefly pink.

3. Many granulites.

4. Many granites.

5. Pegmatite.

6. Markfieldite.

7. Dolerites (common).

8. Felsite.

9. Basalts (common).

10. Three types of rhyolites.

The last is an important point, owing to their practically negligible development in the east of Scotland.

(c) Sedimentary:

1. Carboniferous chert.

2. Arkose (Sparagmite).

In conclusion I should like to express my gratitude to Dr. Bonney and Dr. Rastall for their great kindness in identifying many of the specimens. 